\title{
Matthew 5:17 and Matthew's Community
}

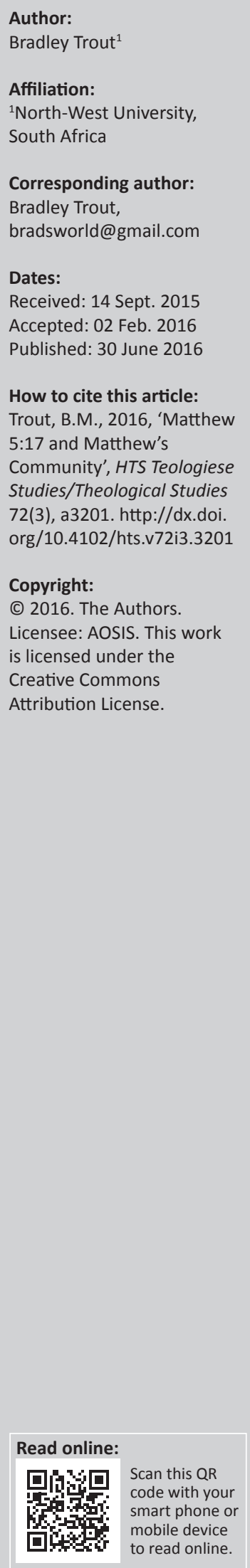

One of the central arguments in establishing the 'Christian-Jewish' nature of the Matthean community is the argument that Matthew's community was law observant. In particular, Matthew 5:17-19 is said to argue in favour of a community that had not broken ties with Judaism. This paper argues that Matthew 5:17-19 is not primarily about demonstrating lawobservance, but fulfilment. When $\pi \lambda \eta \rho$ ó $\omega$ is understood in light of its broader Matthean usage, it becomes apparent that 'to fulfil' means the coming about of what the law and prophets anticipated. What is therefore in focus is not the conservative nature of the community, but the arrival of Israel's hope. This is further demonstrated by the inclusion of 'the prophets', which also points to the coming of Jesus, as well as by the antitheses of 5:21-48, which demonstrates the Christological focus of the passage. More prominent than Jesus' view of the law is the law's (and prophets') view of Jesus. An additional factor pointing in this direction is the prominence of the kingdom in this section of Matthew's gospel. Following on from the declaration in 4:17, the kingdom of heaven remains central throughout the Sermon on the Mount, not least in 5:17-20. When this theological motif is taken into account, it confirms that 5:17-20 has in view the fulfilment of the Jewish hope that God's kingdom would come. What God's people have awaited - as anticipated in the law and prophets - has arrived. Reading this passage as if it were a treatise on the Matthean community's view of the law overlooks the theological context and makes that which is peripheral (conservatism on the law) central, while what is central (fulfilment in that the kingdom has come) is made peripheral. This passage ultimately points to the newness brought about by Jesus and the kingdom of God. Scholars who find support for a conservative community in Matthew 5:17 have failed to reckon sufficiently with the nature of fulfilment in this passage.

\section{Introduction}

The ongoing discussion regarding the nature of the Matthean community is important for a number of reasons. Firstly, it has bearing on the discussion of whether Matthew was anti-Semitic or not, because it clarifies who his opponents were (Sim 1998:5). Secondly, it clarifies several major exegetical matters within the gospel itself. ${ }^{1}$ Thirdly, as Sim (1998:215ff) has laboured to demonstrate, it has massive implications for how we understand this gospel and its relationship to the Gentile world. Little wonder, then, that debate as to the precise nature of the Matthean community continues to dominate Matthean scholarship (cf. Gurtner 2011:26-31; Senior 2011:3ff).

The past couple of decades have produced at least two major positions on this question. The first places the emphasis on the Jewish nature of Matthew's community. For example, Saldarini's (1994) monograph on the subject, Matthew's Christian-Jewish Community, argues that 'The Matthean group is a fragile minority still thinking of themselves as Jews and still identified with the Jewish community by others'. Sim (1998:5) agrees, adding that we should 'understand Matthew's community as a sectarian group in conflict with a Jewish body'. Saldarini establishes this position and related points by showing (1) the diversity of late first-century Judaism; thus those who followed Jesus were aligned to one of multiple expressions of the Jewish life (1994:11-26); (2) that Matthew's use of terms such as 'Israel', 'people', and 'crowds' indicates that he understood his community to be Jewish (1994:27-43); (3) that the evident conflict in the gospel is not between Matthew's Christian community and the Jews, but with the present Jewish leadership (1994:44-67); (4) that 'nations' in Matthew does not refer to the replacing of Israel with the Gentiles (1994:68-83); (5) that sociological studies do not allow for clear-cut distinctions between Judaism and Christianity (1994:84-123); (6) that Matthew's discussions of Jewish law and customs match the legal debates of first-century Judaism (1994:124-164); and (7) that the gospel's Christology aligns well with the thought-world of first-century Judaism (1994:165-193). ${ }^{2}$ 
The second major position places the emphasis on the Christian nature of Matthew's community. For example, Stanton has argued that 'Jewish Christian' better defines Matthew's community (1992:124; cf. Gurtner 2011:28). His argument is based on (1) passages in Matthew referring to 'their synagogues' (4:23; 9:35; 10:17; 12:9; 13:54), which indicate a break between Jesus' disciples and the synagogue; (2) Matthew's emphasis on the church as standing in opposition to the synagogue $(16: 18 ; 18: 17)$; and (3) Matthew appearing to see the kingdom as having been transferred to a 'new people' (1992:131; Matthew 21:43; cf. Olmstead 2011:115-132). More recently, Hagner (2003:194) has also argued that we should see the Matthean community as having moved beyond Judaism: 'My thesis is that there is a radical newness in the Gospel of Matthew that continually moves beyond the bounds of Judaism and requires the conclusion that Matthew's community be described as a form of Christianity' ${ }^{3,4}$

One of the key issues in this discussion is the place of Matthew 5:17-19 and of Matthew's view of the law. For the likes of Saldarini and Sim, such passages demonstrate that Matthew's community completely accepted the validity of the Mosaic law, which shows their thoroughly Jewish orientation ${ }^{5}$ :

The definitive evidence that Matthew's group was still within the orbit of Judaism comes not from the witness of a few Gospel passages but from the general perspective from which the evangelist writes. That is to say, Matthew writes from a thoroughly Jewish outlook and he constantly affirms the basic and distinctive tenets of Judaism. Of the most importance in this regard is his complete acceptance of the validity of the Mosaic law. (cf. 5:17-19, Sim 1998:5)

Later in his monograph, Sim discusses these verses at greater length, concluding:

These three sayings of the Matthean Jesus therefore affirm in the clearest of terms the continuing validity of the whole Mosaic law until the parousia.... It is therefore legitimate to assume that the Matthean community both accepted the importance of the Torah and attempted to keep it in its entirety. (1998:126)

But is this what Matthew 5:17-19 demonstrates? This paper will argue that Matthew 5:17-19 does not support the hypothesis that the Matthean community was primarily Jewish in orientation. In order to demonstrate this we will need to discuss several exegetical and theological details in this famous and disputed passage. In particular, this study will be conducted utilising the historical-critical method ${ }^{6}$ of

3.Hagner's argument is based on (1) Matthew's own affirmation of both continuity and discontinuity (cf. 13:52); (2) the fact that Matthew 5:17-19 points not so much to the law as to the Messiah (more on this below); (3) the 'Jesus-centred' as opposed to 'Torah-centred' nature of the gospel.

4.A recent volume of essays on Matthew's gospel, Jesus, Matthew's Gospel and Early Christianity (2011), demonstrates the divide in scholarship over this issue. While Runesson's essay on judging Gentiles in Matthew's gospel (2011:133-151) supports the conclusions of Saldarini and Sim, Olmstead's essay on "है $\theta v o \varsigma$ in Matthew 21:43 (2011:115-132) supports the conclusions of Stanton and Hagner. The discussion shows no signs of abating (cf. Deines 2008:53-84; Foster 2004; Tuckett 2011:99-129.)

5.For Overman, high regard for the law is among the surest signs of a Jewish community.

6.Cf. Hagner and Young (2009:11-43), who describe this method and its relevance for Matthean studies at length in their The Historical-Critical Method and the Gospel of Matthew (2009:11-43). Here they 'outline an approach to the [historical-critical exegesis. This will involve discussing (1) Matthew's use of $\pi \lambda \eta \rho$ ó $\omega$; (2) Matthew's reference to the law and the prophets; (3) the role of the so-called antitheses of 5:21-48; and (4) the place of the kingdom of God in Matthew's understanding of fulfilment. Finally, we will consider some potential objections to the argument we advance.

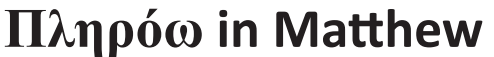

Much debate surrounds the meaning of the term $\pi \lambda \eta \rho$ ó $\omega$ in Matthew's gospel. Davies and Allison present a useful taxonomy of nine positions on the matter in their first ICC volume on Matthew. ${ }^{7}$ But the list could probably be shortened to five positions: ${ }^{8}$

1. Fulfil as uphold. To 'fulfil' the law means it is being 'upheld' or 'confirmed'. This is based on the contrast between $\pi \lambda \eta \rho o ́ \omega$ and $\kappa \alpha \tau \alpha \lambda \dot{v} \omega$, as well as on the historical context in which Jesus is being charged as a lawbreaker (cf. Charles 2002; Wenham 1979).

2. Fulfil as Jesus' obedience. Here $\pi \lambda \eta \rho$ ó $\omega$ is taken to be referring more to Jesus' deeds than to his teaching. Again the contrast with $\kappa \alpha \tau \alpha \lambda \dot{v} \omega$ is important, because it suggests that Jesus' obedient practice is in view. Jesus, then, 'fulfils' the demands of the law and the prophets through his obedience; Jesus keeps the law (cf. Luz 2007:213f).

3. Fulfil as the realisation of the law's intended meaning. In this view, 'to fulfil' refers to Jesus as the one who brings out the intended meaning of the law. Jesus brings out the true meaning of the law through his definitive interpretation (cf. Hagner 1993). ${ }^{9}$

4. Fulfil as transcend. This position is based largely on the 'antitheses' of 5:21-48. In these six contrasts, the law is not abolished but transcended. It is thereby made clear that Jesus' demands do not lead to the abandonment of the law; rather they provide a more perfect picture of God's will (cf. Davies \& Allison 1988:486; Westerholm 1992).

5. Fulfil as the realisation of what the law anticipated. Here 'to fulfil' is taken in its normal Matthean sense (see below) that what was previously anticipated in the law and the prophets has now been realised in the ministry of Jesus (cf. Banks 1975; Deines 2008; France 2007; Meier 1991; Moo 1984).

Although each of these views has some warrant in the text, it is the fifth - 'fulfil' as the realisation of what was

$$
\begin{aligned}
& \text { method] that includes a rationale for its continued use'. See also Hagner (2012:5f); } \\
& \text { Milton Terry ( } 1999: 203) \text { : 'The grammatico-historical sense of a writer is such an } \\
& \text { interpretation of his language as is required by the laws of grammar and the facts of } \\
& \text { history." } \\
& \text { 7.They list nine of 'the gamut of possible interpretations' of the nature of 'fulfil': } \\
& \text { (1) 'fulfil' means 'add to'; (2) 'fulfil' means 'establish', 'make valid', or 'bring into } \\
& \text { effect'; ( } 3 \text { ) 'fulfil' means 'obey'; ( } 4 \text { ) Jesus 'fulfils' the law by observing it perfectly in } \\
& \text { his own person and ministry; (5) Jesus 'fulfils' the law by bringing in a new law which } \\
& \text { transcends the old; ( } 6 \text { ) 'fulfil' means that Jesus brings out the Torah's original } \\
& \text { intention and expands its demand; ( } 7 \text { ) Jesus 'fulfils' the law by enabling others to } \\
& \text { meet the Torah's demands; (8) Jesus 'fulfils' the law by bringing a new righteousness, } \\
& \text { namely the spirit of love; (9) 'fulfil' is eschatological: Jesus fulfils the Torah's }
\end{aligned}
$$
prophecies (1988:485f).

8.See Trout (2015) for a more detailed summary.

9.This is the position held by Sim: 'Jesus the Messiah provides the authoritative and definitive exegesis of the law; he fulfils the law by bringing out its original intention and meaning' (1998:124). It is interesting that Sim and Hagner hold the same view of what $\pi \lambda$ noó $\omega$ here means, whilst disagreeing significantly on how this passage of what $\pi \lambda$ n $\rho$ o $w$ here means, whilst disagreeing significantly on how this passage contributes to the discussion of Matthew's community. Perhaps the implications of
how 'fulfilment' in Matthew is to be understood have not been sufficiently brought how 'fulfilment' in Matthew
to bear on this discussion. 
anticipated - that is exegetically most defensible. Matthew's general use of the verb provides very strong support for this reading of the text.

The verb $\pi \lambda \eta \rho$ ó $\omega$ is used sixteen times in Matthew, ${ }^{10}$ and in almost every instance it is uniquely Matthean. For this reason France has called 'fulfilment' 'the central focus of [Matthew's] theology' (1989:166). On ten occasions the clause 'to fulfil what had been spoken by the prophet, saying ...' introduces a reference to the Old Testament. Each time, the formula suggests that the trajectory set by the original context has reached it culmination in Jesus. The law and the prophets the Old Testament - foreshadowed events which have now come about in the ministry of Jesus. ${ }^{11}$

The evangelists' general understanding of $\pi \lambda \eta \rho$ ó $\omega$ should inform our understanding of 5:17. In the same way as, for example, Mary's bearing of a son who will save his people from their sin 'fulfils' what God said through Isaiah (7:14), Jesus has come to 'fulfil' what the law and prophets anticipated. To 'fulfil' means to bring to completion a trajectory which Old Testament events and teaching set in motion. $^{12}$

On this understanding of $\pi \lambda \eta \rho$ ó $\omega$ it is difficult to see how Matthew 5:17'affirm(s) in the clearest of terms the continuing validity of the whole Mosaic law until the parousia' (Sim 1998:126). If $\pi \lambda \eta \rho$ ó $\omega$ means here what it means elsewhere in Matthew - that what the law and prophets pointed to has arrived - then the validating of the law cannot remain unaffected. Rather than demonstrating the conservative nature of Matthew's Jesus, then, this passage shows, along with so many passages in Matthew's gospel, that Jesus is the fulfilment of Israel's hopes. ${ }^{13}$ The 'Christian Judaism' view has failed to consider sufficiently the meaning and significance of $\pi \lambda \eta \rho o ́ \omega$ in this passage.

\section{Law and prophets}

Although Matthew 5:17 is often treated as if it referred only to Jesus' view of Torah, it is important to note that the 'prophets' are included as well. What God requires of his people is laid out by the law and the prophets, not the law exclusively. Moreover, the concept of fulfilment is here introduced, because it is God's entire revelation that Jesus fulfils (Hagner 1993:105). The inclusion of 'the prophets' indicates that more is in view here than illustrating Jesus' / Matthew's conservative stance: Jesus (if we follow Matthew's understanding of $\pi \lambda \eta \rho{ }^{\prime} \omega$ as above) brings to a climax all that God has said in the law and the prophets. Matthew has salvation history in focus, not merely the debates of his community.

10.1:22; $2: 15,17,23 ; 3: 15 ; 4: 14 ; 5: 17 ; 8: 17 ; 12: 17 ; 13: 35,48 ; 21: 4 ; 23: 32 ; 26: 54,56$; $27: 9$

11.For this or similar readings of the fulfilment passages, cf. France 1989:166-205; Meier 1991; Thielman 1999:51; Turner 2008:22.

12.Cf. Hamilton 2008:230ff.

13.Cf. Hagner's response to Sim's claim that the law occupies a central place in Matthew: 'On the contrary, it is Jesus the Messiah, not the law, that is at the cente of Matthew' (2003:202)
This is further illustrated by another occasion in which Matthew lists 'law and prophets' together. Matthew 11:13 shows us how Matthew understands the prophetic function of both the prophets and the law. Salvation history is clearly in view. The Jewish Scriptures - the prophets and the law pointed towards something that has arrived in the ministry of John the Baptist. The sense in 5:17 is similar: the law and prophets pointed towards (prophesied) the fuller revelation of God's will that came with the time of fulfilment in Jesus' ministry (France 2007:431). So prophets and law point towards the coming of Jesus. The inclusion of 'prophets' here cautions against treating this passage as if it dealt exclusively with Torah.

\section{The 'antitheses' of 5:21-48}

It is well recognised that Matthew's so-called 'antitheses' expand on the 'greater righteousness' of 5:20; they illustrate the nature of the 'righteousness' God demands. ${ }^{14}$ But they also relate back to 5:17. Thielman has noted that 'the programmatic statement about the law's fulfilment in 5:17-20 should be interpreted in light of the antitheses in 5:21-47' (1999:49). ${ }^{15}$ It is certainly important to consider the antitheses when discussing the interpretation of 5:17-19 and its contribution to our understanding of Matthew's community. While Sim does explore the contribution of the antitheses (1998:129ff), he does so in relation to 5:20, not to 5:17. For Sim, the antitheses should be read 'as intensification rather than abrogation' (1998:130). But these are not the only two options. Sim fails to read these verses in light of 5:17.

These verses have been understood in three main ways: (1) as Jesus' interpretation of the law (cf. Hagner 1993:111); (2) as Jesus' deepening or 'radicalising' of the law (cf. Hill 1978:119); or (3) as a demonstration of Jesus' divine authority over the law (cf. France 2007:199). This third view highlights the Christological focus of the section; both the 'but I say to you' and the response of the crowds at the conclusion of the sermon (7:28-29) illustrate that it is Jesus' authority that is in view in this passage.

What does this Christological focus mean for our understanding of 5:17? It shows that it is Jesus, not the law per se, that is in view in this section. ${ }^{16}$ Roland Deines states that

5:17 may be compared to the preamble of a new treaty that relates what will be in force from now on but based on an existing foundation. There are no hints in the text that indicate that this verse needs to be understood as a demand for a special Lawobservant party. (2008:75)

In other words, something much greater than showing Jesus' / Matthew's community's conservative bent is at work here. The passage, in keeping with Matthew's gospel as a whole, is making a Christological point: it is to Jesus, not the law, that disciples are to look for a definitive statement of 14.Cf. Carter 2004:88; Davies \& Allison 1988:504; France 2007:194; Guelich 1982. 15. Recently, Nolland has argued that 5:17 ensures that the antitheses are not taken as Jesus' annulling of the law (Nolland 2005:228; cf. Talbert 2004:59).

16.Banks also made this point in his Jesus in the Synoptic Tradition (1975) 
God's will. We find this at the end of the sermon, too, where it is Jesus' words - not the law - which disciples must obey (7:24-27). Furthermore, at the close of the gospel we read that disciples are to be taught to obey Jesus' teaching - not the law (28:20; cf. Tuckett 2011:127). When we read this passage in light of Matthew's greater presentation of Jesus, it becomes increasingly apparent that Matthew 5:17ff is about much more than a conservative position on the law.

One of the dangers of placing an emphasis on the historical circumstances in which Matthew was written (in this case on the nature of Matthew's community) is that it can - perhaps unintentionally - detract from Matthew's theological concerns. While it is frequently asserted that this passage demonstrates the conservative nature of the Matthean community, it seems that a major theological motif of Matthew's has often been overlooked. ${ }^{17}$ What is at work in this passage needs to be understood in relation to the kingdom of God that Jesus has inaugurated.

\section{The Kingdom of God}

This paper contends that the theme of the 'kingdom of God/ heaven ${ }^{18}$ has received insufficient attention in treatments of Matthew 5:17ff, with the result that the passage has been taken as demonstrating the conservative nature of the Matthean community. When we consider the prominence of this theme in Matthew's gospel, the Sermon on the Mount, and in particular Matthew 5:17-20, we will see that this passage does not sit as comfortably with the 'Christian Judaism' position as has often been thought.

\section{Kingdom of God in Matthew}

It is certain that the kingdom of God was central in the teachings of Jesus, ${ }^{19}$ and Matthew is no exception. The noun

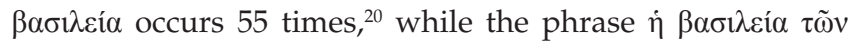

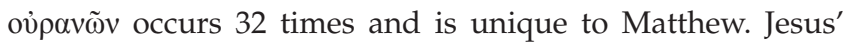
public ministry is kicked off with the declaration that 'Jesus began to proclaim, "Repent, for the kingdom of heaven has come near"' (4:17; NRSV). God's kingdom is in view at the beginning of the first discourse $(5: 3,10)$ as well as at the end of the last discourse (25:34). Central to Matthew's purposes is to show that in Jesus the Messiah, God's kingdom has been inaugurated..$^{21}$

\section{Yet not always; cf. Westerholm 1992. \\ 18.I am aware that more is at work in Matthew's use of the phrase 'kingdom of heaven' than 'reverential circumlocution'. Pennington has, in my view successfully, shown that "Matthew's "kingdom of heaven" language is but one part of an elaborate theme of "heaven and earth" woven all throughout the first gospel" (Pennington 2008:46). Therefore, the reverential circumlocution view is to be rejected. Nonetheless, this paper treats 'kingdom of God' and 'kingdom of heaven' as interchangeable when referring to Matthew's concept of the arrival of God's} reign.

19.'That the focus of Jesus' preaching and teaching was the kingdom of God is universally acknowledged' (Farmer 1987:126). 'Today, there is a general consensus among New Testament scholars that the theme of the imminent coming of the kingdom is central to the preaching of the historical Jesus' (Hannan 2006:1).

20.The term occurs 121 times in the Synoptic Gospels.

21.A recent essay on the 'Kingdom of God in the New Testament' focuses heavily on Matthew's gospel because 'its kingdom pronouncements are so numerous and pregnant with meaning' (Yarbrough 2012:108).

\section{Kingdom of God in the Sermon on the Mount}

God's kingdom is clearly in focus in the Sermon on the Mount. This has been well drawn out by Yarbrough (2012:113-115):

1. The Beatitudes are bookended by references to the kingdom $(5: 3,10)$.

2. The beginning (5:17-20) of the central section makes it clear that the kingdom remains in view, because disciples who relax the law will be called least in the kingdom, and disciples who fail to exhibit greater righteousness will face exclusion from it.

3. Perhaps the central request of the Lord's Prayer is that God's kingdom would come (6:10).

4. The kingdom is to be the disciples' priority (6:33).

5. Entry into the kingdom is in view at the Sermon's close, where Jesus makes it clear that only those who do the will of God will receive entry into it (7:21).

The second point above draws attention to the prominence of the kingdom of God in Matthew 5:17-20, where the kingdom of heaven is mentioned three times (vv. 19-20). It is clear that Matthew continues to elaborate on the nature of the kingdom that Jesus has inaugurated $(4: 17,23)$. What is in view, then, is the fulfilment of the Jewish hope. ${ }^{22}$ In Jesus, all that God's people have longed for - as anticipated in the law and prophets - has arrived. The prominence of the kingdom in Matthew in general, and in the Sermon on the Mount - including 5:17-20 - in particular, illustrates that in this passage it is God's kingdom that is in view, not the conservative nature of the Matthean community. Reading this passage as if it were a treatise on the Matthean community's view of the law overlooks the theological context and makes that which is peripheral (conservatism on the law) central whereas what is central (fulfilment in that the kingdom has come) is made peripheral. This passage does not therefore support the 'Matthew's Christian-Jewish Community' position to the extent that has been supposed. Two further points support this conclusion.

Firstly, both Jewish and Christian communities have a high view of the Old Testament and believe, in some sense, in its continuity. ${ }^{23}$ For example, one might easily demonstrate a high view of the Old Testament in the Pauline communities (e.g. Rom. 3:31; 7:12, 16, 22; 1 Cor. 9:8), despite antinomian sentiments expressed here and there. ${ }^{24}$ Therefore, showing the 'conservative' orientation of these verses hardly contributes to answering the question of the nature of the Matthean community.

22.This follows the understanding of the kingdom of God as set out, for example, in Wright: 'Most were hoping, some fervently, for a new turn in Israel's fortunes. If there is one creator god, and Israel is his people, then this god must act sooner or later to restore her fortunes. Israel is still in a state of 'exile', and this must be put right' (1992:280; cf. Beasley-Murray 1992:19; Westerholm 2006:81f).

23.Cf. Tuckett: 'In a very real sense, no Christian writer ever ignored or rejected the Jewish Law in toto' (2011:106).

24.Again, Tuckett: 'Even Pauline "Gentile Christians" were expected to adopt a significant measure of "Jewishness" in their version of "Christianity"' (2011:107). 
Secondly, several passages in Matthew's gospel point in the opposite direction from the lines taken by Saldarini and Sim. Deines (2008:64-69) provides references and a brief discussion of many such texts. ${ }^{25}$ He concludes that 'there are more hints in the texts which support the impression that the Law is not central in Matthew's description of Jesus' ministry' (2008:69f). ${ }^{26}$ This supports our contention that in Matthew $5: 17$ it is not so much the law that is in focus as it is salvation history. The kingdom of God, to which the law and prophets pointed, has come. Matthew 5:17-48 demonstrates this and draws out the implications for the law.

\section{Objection: Matthew 5:18-19}

It may be objected that this paper has dealt primarily with $\pi \lambda \eta \rho$ ó $\omega$ in 5:17, whereas it is verses 18-19 that demonstrate the strongly conservative view of the Matthean community on the law. So Sim, commenting on 5:19, states: 'It is this verse in particular which demonstrates that obedience to the law was a practical concern of the Matthean community' (1998:126). In response several comments may be made.

1. We have already pointed out that both 5:17 and the antitheses make a Christological point about Jesus' coming - it was him that the law and prophets anticipated (5:17); it is to him that we now listen (5:21-48). Therefore, 5:18-19 must be interpreted within these motifs rather than becoming the hermeneutical lens through which we read them. In short, exegetically 5:18-19 - as indicated by the $\gamma$ à $\rho$ (v. 18) and the oũv (v. 19) - serve to clarify 5:17, not vice versa.

2. In particular, the antitheses of 5:21-48 make it clear that 'not one letter, not one stroke of a letter, will pass from the law' (NRSV) does not mean that the law undergoes no changes. Not all of these contrasts support the radicalisation argument. For instance, Jesus' statements on divorce ${ }^{27}$ and oaths ${ }^{28}$ certainly allow for a measure of change. Jesus' relationship with the law must be seen in light of the dawning kingdom of God, in which a departure from the law does not necessarily imply its abrogation (cf. Westerholm 1992:47). ${ }^{29}$

3. All this strongly implies that the law's continuity should be understood in light of its fulfilment: 'In all its details, the Scripture remains authoritative, but the manner in which men are to relate to and understand its provisions is now determined by the one who has

25.As 'texts supporting a new understanding of the Torah in the Kingdom of God', Deines lists: Matthew $5: 21-48 ; 7: 12 ; 8: 3,22 ; 9: 10 f ; 11: 11-15,28-30 ; 12: 1-8$, Deines lists: Matthew 5:21-48; 7:12; 8:3, 22; 9:10f; 11:11-15,
9-14; 15:1-11, 32-39; 16:19; 17:24f; 18:3; 19:3-9; 21:12f, 31f.

26.Cf. the discussion of Sabbath observance, food laws, and circumcision in Tuckett for a similar conclusion questioning how 'conservative' Matthew really was (2011 116-127)

27.Sanders, even though arguing that Jesus did not oppose or reject the law, admits that the passage on divorce shows 'that the Mosaic dispensation is not adequate' (Sanders 1985:260; cf. Meier 2009:126f).

28.Cf. Meier (2009:205): 'the prohibition of oaths can take its place alongside the prohibition of divorce as a second example of the historical Jesus' revocation of individual institutions and/or commandments of the Mosaic Law'.

29.Westerholm adds: '[Matthew] insists that the kingdom righteousness which Jesus proclaims does not fall short of the demands of Moses, nor lead to indifference toward its requirements; rather it transcends them, a more perfect embodiment of the divine will' (1992:47). fulfilled it' (Moo 1984:27). The smallest strokes of the law's letters will not be abandoned, but they are to be seen in a new way. It is this new way that the antitheses explain. ${ }^{30}$

4. While the admonition to do and teach these commandments $\left(\dot{\varepsilon} v \tau 0 \lambda \tilde{\omega} v^{31}\right)$ (v. 19) may indicate that Matthew wishes to counteract antinomianism in his community, 32 it is important to note that, of the 14 occurrences of $\delta 1 \delta$ ó $\sigma \kappa \omega$ in Matthew, only 2 (5:19; 28:20) have the disciples as the subject. In 5:19 they are to teach others to do the law, but in 28:20 they are to teach everything Jesus commanded. So although they are to teach others to obey the law, they are ultimately to teach it in its 'fulfilled' sense; that is, in the teachings of Jesus (cf. France 2007:188).

For these reasons, 5:18-19, rather than illustrating a lawobservant Matthean community, show that the law remains intact, even under the new conditions brought about by the arrival of the kingdom. But fulfilment does entail a measure of change, which the gospel as a whole illustrates. The passage certainly does demonstrate a high view of the law; but God's people have for the most part always been 'law-observant'; this is not a particular trait of Judaism.

\section{Conclusion}

Hagner is right that Matthew 5:17-20 'will not bear the weight of the hypothesis' (2003:208) which argues that Matthew represents 'Christian Judaism'. His reasons for this conclusion include the radical newness of the message presented in Matthew's gospel. In this paper we have advanced an additional argument in favour of the 'newness' presented by Matthew. Far from merely illustrating the conservative nature of the Matthean community, Matthew 5:17ff presents Jesus as the one to whom the law and prophets pointed. In 5:19 they are to teach others to do the law, but in 28:20 they are to teach everything Jesus commanded. This means that the kingdom of God, long anticipated by Judaism, has arrived in the ministry of Jesus. It is the arrival of the kingdom that takes centre stage in the gospel in general, and Matthew 5:17-20 in particular, not the law. Matthew 5:17, therefore, argues in favour of the 'newness' position. Scholars who find support for a conservative community in Matthew 5:17 have failed to reckon sufficiently with the nature of fulfilment in this passage.

\footnotetext{
30.cf. Deines: 'Against the nearly unanimous view to the contrary, it can be shown that the rabbinic texts that are regularly adduced for the interpretation of $5: 18$ cannot be used to support the view that Matthew favors a law-abiding position which lays emphasis on every single detail or on ever "small" law. On the contrary, the everlastingness of each jot and stroke is a confession of the invariability and irreversibility of scripture' (2008:76).

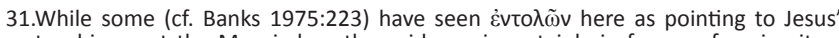
teaching, not the Mosaic law, the evidence is certainly in favour of seeing it as referring to Old Testament commandments: (1) the oũv links us to what precedes;

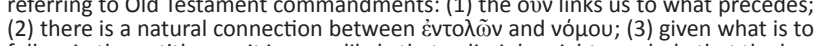
(2) there is a natural connection between $\dot{\varepsilon} v \tau o \lambda \tilde{v} v$ and vómou; (3) given what is to
follow in the antitheses, it is more likely that a disciple might conclude that the law might have been annulled, which Jesus categorically denounces (cf. Davies \& Allison 1988:496; Hagner 1993:108).
}

32.Cf. Davies \& Allison 1988:485f; Hagner 1993:109. 


\section{Acknowledgements Competing interests}

The author declares that he has no financial or personal relationships which may have inappropriately influenced him in writing this article.

\section{References}

Banks, R., 1975, Jesus and the Law in the synoptic tradition, Cambridge University Press, Cambridge, (Society for New Testament Monograph Series, 28).

Beasley-Murray, G.R., 1992, 'Kingdom of God in the teaching of Jesus', Journal of the Evangelical Theological Society 35(1), 19-30.

Carter, W., 2004, Matthew: Storyteller, interpreter, evangelist, rev. edn., Hendrickson, Peabody.

Charles, J.D., 2002, 'Garnishing with the "greater righteousness": The disciple's relationship to the Law (Matthew 5:17-20)', Bulletin for Biblical Research 12(1), $1-15$.

Davies, W.D. \& Allison, D.C., 1988, Critical and exegetical commentary on the Gospel according to Saint Matthew, Matthew 1-7, vol. 1, T\&T Clark, Edinburgh (International critical commentary).

Deines, R., 2008, 'Not the Law but the Messiah: Law and righteousness in the Gospel of Matthew - An ongoing debate', in D.M. Gurtner \& J. Nolland (eds.), Built upon the rock: Studies in the Gospel of Matthew, pp. 53-84, Eerdmans, Grand Rapids, MI.

Farmer, R, 1987, 'The kingdom of God in the Gospel of Matthew', in W. Willis (ed.), Kingdom of God in 20th century interpretation, pp. 119-130, Hendrickson, Kingdom
Peabody.

Foster, P., 2004, Community, Law and mission in Matthew's Gospel, Mohr, Tübingen. (Wissenschaftliche Untersuchungen zum Neuen Testament 2. Reihe, 177).

France, R.T., 1989, Matthew evangelist and teacher, Zondervan, Grand Rapids, MI.

France, R.T., 2007, Gospel of Matthew, Eerdmans, Grand Rapids, MI. (New international commentary on the New Testament).

Guelich, R.A., 1982, Sermon on the Mount, Word, Dallas, TX.

Gurtner, D.M., 2011, 'Gospel of Matthew from Stanton to present: A survey of some recent developments', in D.M. Gurtner, J. Willitts \& R.A. Burridge (eds.), Jesus, Matthew's Gospel and early Christianity, pp. 23-38, Bloomsbury, London. (Library of New Testament Studies, 435).

Hagner, D.A., 1993., Matthew 1-13. s.l.: Nelson. (Word biblical commentary, 33a).

Hagner, D.A., 2003., 'Matthew: Apostate, reformer, revolutionary?', New Testament Studies 49(2): 193-209. http://dx.doi.org/10.1017/\$0028688503000109

Hagner, D.A., 2012, New Testament: A historical and theological introduction, Baker Academic, Grand Rapids, MI.

Hagner, D.A. \& Young, S.E., 2009, 'The historical-critical method and the Gospel of Matthew', in M.A. Powell (ed.), Methods for Matthew, pp. 11-43, Cambridge University Press, Cambridge.

Hamilton, J.M., Jr., 2008, “"The virgin will conceive": Typological fulfillment in Matthew 1:18-23', in D.M. Gurtner \& J. Nolland (eds.), Built upon the rock: Studies in the Gospel of Matthew, pp. 228-247, Eerdmans, Grand Rapids, MI.
Hannan, M., 2006, Nature and demands of the sovereign rule of God in the Gospel of Matthew, T\&T Clark, London. (Library of New Testament Studies, 308).

Hill, D., 1978, Gospel of Matthew, Oliphants, London. (New century Bible).

Luz, U., 2007, Matthew 1-7, transl. J.E. Crouch, Fortress Press, Minneapolis, MN. (Hermeneia).

Meier, J.P., 1991, Vision of Matthew, Crossroad, New York.

Meier, J.P., 2009, Marginal Jew Volume 4: Law and Love, New Haven, Yale University Press.

Moo, D.J., 1984, 'Jesus and the authority of the Mosaic Law', Journal for the Study of the New Testament 20, 3-49.

Nolland, J., 2005, Gospel of Matthew, Eerdmans, Grand Rapids, MI. (New international Greek Testament commentary).

Olmstead, W.G., 2011, 'Gospel for a new nation: Once more, the $\dot{\varepsilon} \theta v o \varsigma$ of Matthew 21:43', in D.M. Gurtner, J. Willitts \& R.A. Burridge (eds.), Jesus, Matthew's Gospel and early Christianity, pp. 115-132, Bloomsbury, London. (Library of New Testament Studies, 435).

Pennington, J.T., 2008, 'The Kingdom of Heaven in the Gospel of Matthew', Southern Baptist Journal of Theology 12(1), 44-51.

Runesson, A., 2011, 'Judging Gentiles in the Gospel of Matthew: Between 'othering' and inclusion', in D.M. Gurtner, J. Willitts \& R.A. Burridge (eds.), Jesus, Matthew's Gospel and early Christianity, pp. 133-151, Bloomsbury, London. (Library of New Testament studies, 435).

Saldarini, A.J., 1994, Matthew's Christian-Jewish community, University of Chicago Press, Chicago, IL.

Sanders, E.P., 1985, Jesus and Judaism, Fortress Press, Philadelphia, PA.

Senior, D., 2011, 'Matthew at the Crossroads of early Christianity: An introductory assessment', in D. Senior (ed.), Gospel of Matthew at the Crossroads of early Christianity, pp. 3-23, Uitgeverij Peeters, Leuven. (Bibliotheca Ephemeridum Theologicarum Lovaniensium, CCXLIII).

Sim, D.C., 1998, Gospel of Matthew and Christian Judaism, T\&T Clark, Bloomsbury.

Stanton, G.N., 1992, Gospel for a new people, T\&T Clark, Edinburgh.

Talbert, C.H., 2004, Reading the Sermon on the Mount, Baker Academic, Grand Rapids, MI.

Terry, M., 1999, Biblical Hermeneutics, Wipf \& Stock, Eugene, OR.

Thielman, F., 1999, Law and the New Testament, Crossroad, New York.

Tuckett, C.M. 2011, 'Matthew: The social and historical context - Jewish Christian and/or Gentile?', in D. Senior (ed.), Gospel of Matthew at the crossroads of early Christianity, pp. 99-129, Uitgeverij Peeters, Leuven. (Bibliotheca Ephemeridum Theologicarum Lovaniensium, CCXLIII).

Turner, D.L., 2008, Matthew, Baker Academic, Grand Rapids, MI. (Baker exegetical commentary on the New Testament).

Wenham, D., 1979, 'Jesus and the Law: An exegesis on Matthew 5:17-20', Themelios $4(3), 92-96$

Westerholm, S., 1992, 'Law in the Sermon on the Mount: Matt 5:17-48', Criswell Theological Review 6(1), 43-56.

Westerholm, S., 2006, Understanding Matthew, Baker Academic, Grand Rapids, MI.

Wright, N.T., 1992, New Testament and the people of God, Fortress Press, Minneapolis, MN.

Yarbrough, R.W., 2012, 'Kingdom of God in the New Testament: Matthew and Revelation', in C.W. Morgan \& R.A. Peterson (eds.), Kingdom of God, pp. 95-123, Crossway, Wheaton, IL. 